\title{
Freshwater molluscs in mountain lakes of the Eastern Alps (Austria): relationship between environmental variables and lake colonization
}

\author{
Robert STURM \\ Brunnleitenweg 41, A-5061 Elsbethen, Austria \\ e-mail corresponding author: robert.sturm@sbg.ac.at
}

ABSTRACT

This study examines the colonization of twelve mountain lakes of the Central Alps in Austria by freshwater gastropods and bivalves. Of the twelve lakes studied, seven are in the montane vegetation level $(600-1400 \mathrm{~m})$, and five are subalpine (1400-2200 $m)$. At each lake, species diversity and abundance was measured by taking 10 samples along the shore, for each parameter. In addition to recording of molluscs, I measured 12 environmental factors, namely, altitude, water temperature, shading, water pH, conductivity, oxygen saturation, biological oxygen demand after 5 days $\left(B O D_{5}\right)$, nitrate concentration, total hardness, mean grain size of the bottom substrate, and percentage of submerged vegetation and algal cover, at each sample site. I then used multivariate statistical analysis, specifically Canonical Correspondence Analysis, to detect any relationships between these physico-chemical factors and the distribution of molluscs.

The study detected a total of 13 mollusc, 8 gastropod and 5 bivalve species in the lakes, with lakes at the montane vegetation level generally exhibiting higher species diversities than lakes at the subalpine vegetation level. Pisidium casertanum, Galba truncatula, P. subtruncatum, and Radix balthica exhibited the highest species abundance, while Acroloxus lacustris and Musculium lacustre, both typical of lower altitudes, were very rare. Multivariate analysis revealed an important influence of shading, altitude, nitrate, BOD, oxygen saturation, substrate grain-size and submerged vegetation on the distribution patterns of most mollusc species. In contrast, the distribution patterns of $\mathrm{P}$. subtruncatum and $\mathrm{P}$. obtusale were highly independent of the measured environmental factors.

Key words: Mountain lake, spatial distribution, molluscs, abundance, Canonical Correspondence Analysis

\section{INTRODUCTION}

In recent decades, scientists have become increasingly interested in Alpine mountain lakes, leading to research covering a wide range of chemical, physical, and biological aspects (e.g. Köck et al. 1995; Sommaruga et al. 1999; Sommaruga 2001; Lami \& Boggero 2006). Sperling (1975) and Frank (1992, 1996) carried out the first significant investigations of terrestrial and aquatic molluscs in the inner-Alpine region, and provided a preliminary impression of the distribution of the malacofauna in various biotopes of the Austrian Alps. At the same time, Turner et al. (1998) conducted a more comprehensive study in the Swiss Alps, and produced partly detailed distribution maps of all gastropod and bivalve species recorded in Switzerland and Liechtenstein. This atlas of the Swiss malacofauna, and its spatial distribution in the Western Alps, still represents a quantum leap in Central European malacological research; no such publication is available, or anticipated, for the Eastern Alps.

Scientific studies of the distribution of freshwater molluscs in the inner-Alpine waters of Austria are still very scarce (e.g. Kuiper 1974; Sperling 1975; Patzner 1995; Sturm 2003, 2004), for two main reasons. First, colonization of mountain lakes and brooks is often limited to the very few species that can tolerate extreme environmental conditions. Second, abundances of such highly tolerant species in their aquatic biotopes are usually very low, which significantly complicates both their detection and quantification. Further, investigations which have attempted to elucidate a possible relationship between distribution patterns of aquatic molluscs and environmental conditions have only been within a close compass (e.g. Sturm 2004, 2005), and have used the mathematical concepts of linear regression as well as Generalized Linear and Generalized Additive Models (GLM and GAM; Hosmer \& Lemeshow 2000). The practice of only recording mollusc abundances semiquantitatively, in defined frequency classes (e.g. class 1 for rare or individual occurrence to class 4 for occurrence in masses; Patzner 1994) has shipwrecked more comprehensive ecological studies. These frequency data were not appropriate for multivariate correspondence analysis, which examines species tolerances over a set of environmental factors (Ter Braak 1986).

This study has two objectives. First, the present work aims to quantitatively study malacological colonization of 12 mountain lakes positioned in the Centrals Alps of Austria (Counties of Salzburg and Styria), and measure environmental factors at each sampling site. Second, the study seeks to use a multivariate ordination technique (Canonical Correspondence Analysis) to decode possible relationships between mollusc distribution patterns and environmental factors. Canonical 
Correspondence Analysis permits complex calculations to be displayed in rather simple two-dimensional graphs. This work should advance our knowledge of the colonization of the Eastern Alps by freshwater molluscs.

\section{MATERIALS AND METHODS}

\subsection{Study site and date of sampling}

All 12 of the investigated lakes are located in the Central Alps of Austria (County of Salzburg and Styria), and three of these lakes are within the core zone of the Hohe Tauern National Park (Fig. 1). The altitudes of the mountain lakes range from $1,056 \mathrm{~m}$ (Kreuzensee) to 2,170 $\mathrm{m}$ (Kratzenbergsee), thus varying between the upper montane and subalpine vegetation zone. All of the lakes are of glacial origin with variable substrate grainsize and content of submerged vegetation (Tab. 1), except for Hintersee, which was formed by a landslip and Lower Bockhartsee and Lower Rotgüldensee, which are both reservoirs dammed for local electricity production. Surrounding vegetation mainly depends upon the geographic position of the lakes, and therefore ranges from diverse grasses, bushes and deciduous trees at lower altitudes to spruce, larch and cembra pines at the subalpine level. At each of the studied lakes, I selected 10 sample points, evenly distributed along the lake shore, for mollusc sampling and measurement of environmental factors, resulting in a total of 120 samples.

Field work occurred from September 2000 to August 2001 during periods of warm weather and decreased rainfall. Sampling and measurement activity along the shore of the lakes took place from late morning $\left(10^{00}\right)$ to the early evening $\left(16^{00}\right)$. I strove to have constant weather conditions during the investigation of a single lake.

\subsection{Recording of aquatic molluscs and environmental factors}

In order to sample and count aquatic molluscs, I placed a $0.5 \times 0.5 \mathrm{~m}$ frequency frame at the sample points, respectively, and recorded all molluses within the frame. At each point, I repeated this procedure four times to cover a total sampling area of $1 \mathrm{~m}^{2}$. I followed the sampling strategy of Patzner (1994) and Glöer \& Meier-Brook (2003), which included the investigation plants and stones for possible colonization by molluscs
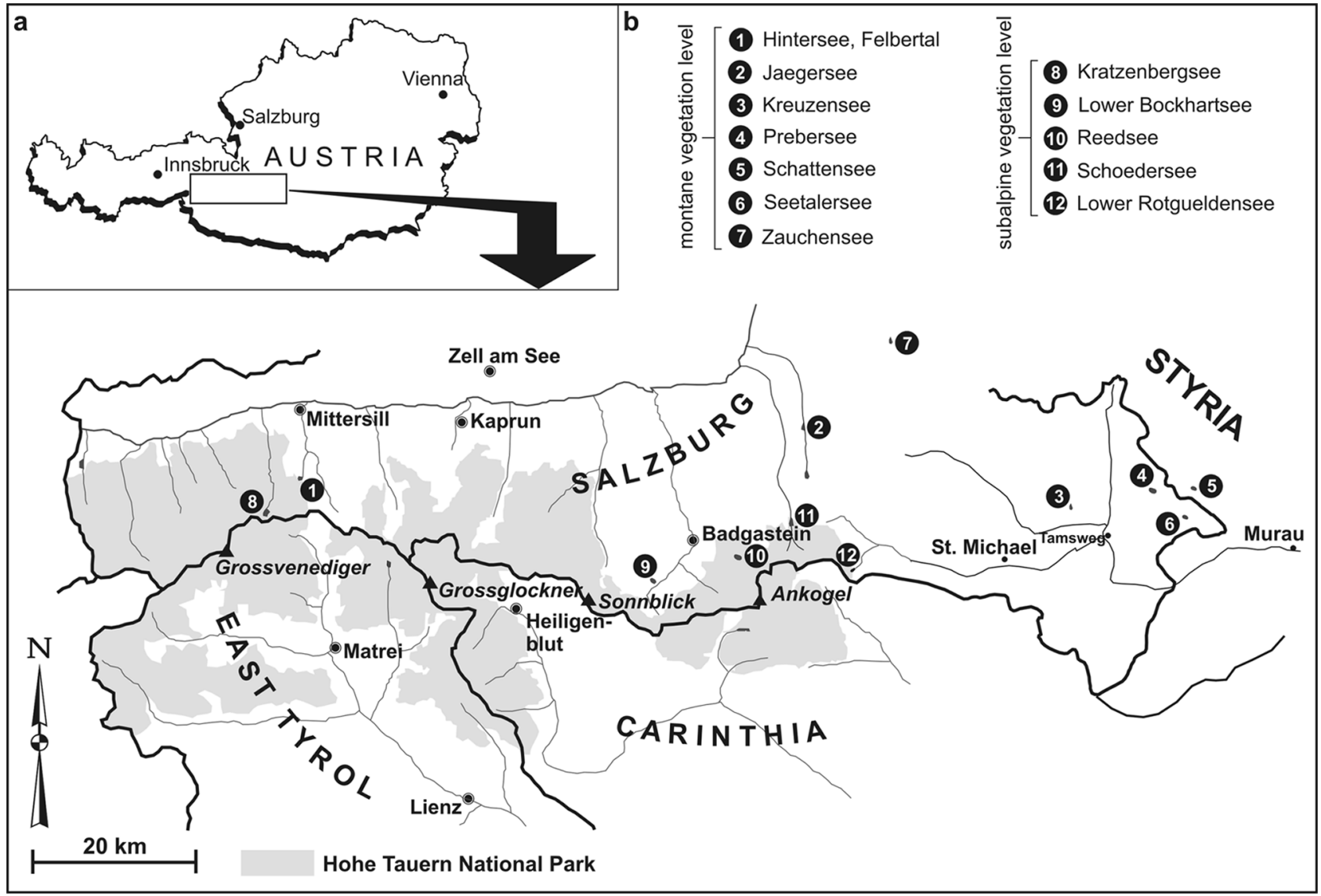

Fig. 1. Map illustrating the geographic position of the investigated mountain lakes within the Eastern Alps. Seven lakes belong to the montane vegetation zone $(600-1400 \mathrm{~m})$ and five lakes to the subalpine vegetation zone $(1400-2200 \mathrm{~m})$. 
Tab. 1. Geographic and morphological characteristics of the investigated lakes.

\begin{tabular}{|c|c|c|c|c|c|c|}
\hline \multicolumn{7}{|c|}{ Brief characterization of the studied lakes } \\
\hline & Lake & $\begin{array}{l}\text { Geogr. pos./ } \\
\text { Altitude }\end{array}$ & Size, Depth & Vegetation & $\begin{array}{l}\text { Ground } \\
\text { substrate }\end{array}$ & Code \\
\hline 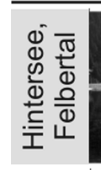 & & $\begin{array}{l}\text { End of the Felber valley, } \\
\text { South of Mittersill, County } \\
\text { of Salzburg } \\
1315 \mathrm{~m}\end{array}$ & $\begin{array}{l}\text { S: } 0.08 \mathrm{~km}^{2} \\
\text { D: } \max .6 \mathrm{~m}\end{array}$ & $\begin{array}{l}\text { Spruces, larchs, } \\
\text { herb vegetation, } \\
\text { dense subm. veg. }\end{array}$ & $\begin{array}{l}\text { Organic substrate mixed } \\
\text { with sand, blocks } \\
\text { of silicate rocks }\end{array}$ & HS \\
\hline 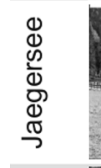 & & $\begin{array}{l}\text { End of the Kleinarl valley, } \\
\text { South of Kleinarl, County } \\
\text { of Salzburg } \\
1105 \mathrm{~m}\end{array}$ & $\begin{array}{l}\text { S: } 0.1 \oslash \mathrm{km}^{2} \\
\text { D: ca. } 5 \mathrm{~m}\end{array}$ & $\begin{array}{l}\text { Mixed forest with } \\
\text { maples, spruces, etc., } \\
\text { herb vegetation along } \\
\text { the western lakeside }\end{array}$ & $\begin{array}{l}\text { Organic substrate mixed } \\
\text { with sand, blocks } \\
\text { of silicate rocks }\end{array}$ & JS \\
\hline 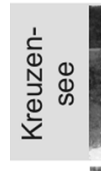 & & $\begin{array}{l}\text { South of the Lessach valley, } \\
10 \mathrm{~km} \mathrm{~W} \text { of Tamsweg, County } \\
\text { of Salzburg } \\
1056 \mathrm{~m}\end{array}$ & $\begin{array}{l}\text { S: } 0.01 \mathrm{~km}^{2} \\
\text { D: ca. } 4 \mathrm{~m}\end{array}$ & $\begin{array}{l}\text { Rich grass and herb } \\
\text { vegetation on the } \\
\text { shore, dense subm. } \\
\text { veg. }\end{array}$ & $\begin{array}{l}\text { Organic substrate mixed } \\
\text { with fine sand }\end{array}$ & KS \\
\hline 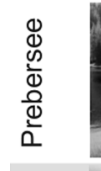 & & $\begin{array}{c}8 \mathrm{~km} \text { NE of Tamsweg, County } \\
\text { of Salzburg } \\
1124 \mathrm{~m}\end{array}$ & $\begin{array}{l}\text { S: } 0.18 \mathrm{~km}^{2} \\
\text { D: ca. } 5 \mathrm{~m}\end{array}$ & $\begin{array}{l}\text { Spruces, pines, and } \\
\text { birch, moor and } \\
\text { grass veg., sparse } \\
\text { subm. veg. }\end{array}$ & $\begin{array}{l}\text { Organic substrate mixed } \\
\text { with sand and } \\
\text { stones of different size }\end{array}$ & PS \\
\hline 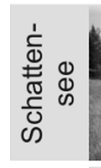 & & $\begin{array}{l}\text { Krakauhintermuehlen } \\
15 \mathrm{~km} \mathrm{NE} \text { of Tamsweg, County } \\
\text { of Styria } \\
1120 \mathrm{~m}\end{array}$ & $\begin{array}{l}\text { S: } 0.03 \mathrm{~km}^{2} \\
\text { D: ca. } 6 \mathrm{~m}\end{array}$ & $\begin{array}{l}\text { Spruces and pines, } \\
\text { dense grass veg., } \\
\text { dense subm. veg. }\end{array}$ & $\begin{array}{l}\text { Organic substrate, } \\
\text { grass, sand, } \\
\text { stones }\end{array}$ & SS \\
\hline $\begin{array}{l}\frac{1}{0} \\
\frac{1}{\pi} \\
\frac{\pi}{\Phi} \\
\mathbb{\infty} \\
\infty\end{array}$ & & $\begin{array}{l}\text { End of the Seetal, } \\
10 \mathrm{~km} \text { E of Tamsweg, County } \\
\text { of Salzburg } \\
1080 \mathrm{~m}\end{array}$ & $\begin{array}{l}\text { S: } 0.10 \mathrm{~km}^{2} \\
\text { D: ca. } 10 \mathrm{~m}\end{array}$ & $\begin{array}{l}\text { Dense moor and } \\
\text { grass veg., trees } \\
\text { along the northern } \\
\text { lakeside }\end{array}$ & $\begin{array}{l}\text { Organic substrate, } \\
\text { grass, mud, moor } \\
\text { vegetation }\end{array}$ & STS \\
\hline 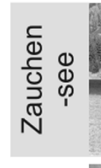 & & $\begin{array}{l}\text { End of the Zauchen valley, } \\
\text { South of Altenmarkt, County } \\
\text { of Salzburg } \\
1339 \mathrm{~m}\end{array}$ & $\begin{array}{l}\text { S: } 0.06 \mathrm{~km}^{2} \\
\text { D: } \max .8 \mathrm{~m}\end{array}$ & $\begin{array}{l}\text { Spruces and herb } \\
\text { vegetation, partly } \\
\text { dense subm. veg. }\end{array}$ & $\begin{array}{l}\text { Organic substrate, sand, } \\
\text { stones of different size }\end{array}$ & ZS \\
\hline 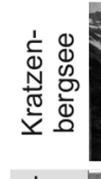 & & $\begin{array}{l}\text { End of the Hollersbach valley, } \\
\text { County of Salzburg } \\
2170 \mathrm{~m}\end{array}$ & $\begin{array}{l}\mathrm{S}: 0.26 \mathrm{~km}^{2} \\
\mathrm{D}: \max .30 \mathrm{~m}\end{array}$ & $\begin{array}{l}\text { Grass vegation } \\
\text { rich of species } \\
\text { (e. g. sedges) }\end{array}$ & $\begin{array}{l}\text { Silicate stones and } \\
\text { blocks }\end{array}$ & KBS \\
\hline 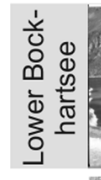 & & $\begin{array}{l}\text { Above Sportgastein, } \\
\text { Gastein valley, } \\
\text { County of Salzburg } \\
1830 \mathrm{~m}\end{array}$ & $\begin{array}{l}\mathrm{S}: 0.16 \mathrm{~km}^{2} \\
\mathrm{D}: \max .12 \mathrm{~m}\end{array}$ & $\begin{array}{c}\text { Sparse vegetation } \\
\text { including herbs and } \\
\text { bushes, no subm. } \\
\text { veg. }\end{array}$ & $\begin{array}{l}\text { Silicate blocks of } \mathrm{cm} \\
\text { to } \mathrm{dm} \text { size }\end{array}$ & LBS \\
\hline 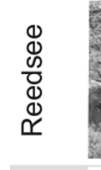 & & $\begin{array}{l}\text { Koetschach valley, } \\
\text { East of the Graukogel, } \\
\text { County of Salzburg } \\
2070 \mathrm{~m}\end{array}$ & $\begin{array}{l}\text { S: } 0.06 \mathrm{~km}^{2} \\
\mathrm{D}: \max .6 \mathrm{~m}\end{array}$ & $\begin{array}{l}\text { Spruces, larchs, } \\
\text { and pines }\end{array}$ & $\begin{array}{l}\text { Medium- to coarse- } \\
\text { grained inorganic } \\
\text { substrate mixed with } \\
\text { organic mass }\end{array}$ & RS \\
\hline 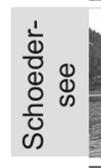 & & $\begin{array}{l}\text { End of the Grossarl valley, } \\
\text { South of Grossarl, } \\
\text { County of Salzburg } \\
1450 \mathrm{~m}\end{array}$ & $\begin{array}{l}\text { S: } 0.10 \mathrm{~km}^{2} \\
\text { D: } \max .2 \mathrm{~m}\end{array}$ & $\begin{array}{l}\text { Moor and grass } \\
\text { vegetation }\end{array}$ & $\begin{array}{l}\text { Organic substrate, } \\
\text { grass, mud }\end{array}$ & scs \\
\hline 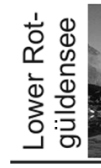 & & $\begin{array}{l}\text { North of the Grosser Hafner, } \\
\text { above Murwinkel, } \\
\text { County of Salzburg } \\
1760 \text { m }\end{array}$ & $\begin{array}{l}\text { S: } 0.15 \mathrm{~km}^{2} \\
\mathrm{D}: \max .10 \mathrm{~m}\end{array}$ & $\begin{array}{l}\text { Sporadic lining by } \\
\text { larchs and pines, } \\
\text { no subm. veg. }\end{array}$ & $\begin{array}{l}\text { Silicate blocks of } \mathrm{cm} \\
\text { to } \mathrm{dm} \text { size }\end{array}$ & LRS \\
\hline
\end{tabular}


and sampling the bottom substrate with a hand sieve (mesh size: $0.5 \mathrm{~mm}$ ). Sampling of fine inorganic sediment mixed with plant fragments and detritic components generally took place to a depth of about $10 \mathrm{~cm}$, in order to include endobenthic molluscs such as pill clams. Sampling was exclusively conducted along the lake shore, to a maximum water depth of $1 \mathrm{~m}$. For aquatic gastropods and bivalves, I only recorded adult and subadult living animals, larval forms and empty shells were excluded. Whenever possible, counting occurred at the sample points, and collected animals were then released to their natural habitats. For muddy ground substrate, sieving occurred in the laboratory and retained material was carefully examined under the stereomicroscope. For each sample point, representatives of the occurring species were stored in $70 \%$ ethanol.

At each sample site, I measured 12 environmental factors, namely, water temperature, $\mathrm{pH}$, conductivity, oxygen saturation, biological oxygen demand after 5 days $\left[\mathrm{BOD}_{5}\right]$, nitrate content, total hardness, altitude, mean grain-size of the bottom substrate, submerged vegetation, and algal cover, and shading. Water measurements occurred in the water layer directly above the sediment, between late morning and early evening. Except for $\mathrm{BOD}_{5}$, which was analyzed in the laboratory after taking a water sample and storing it in a dark box at 10 ${ }^{\circ} \mathrm{C}$, I measured all physical and chemical properties using portable instruments or single use analysis probes (Stelzner $\mathrm{GmbH}$ ). I determined the mean grain size of the bottom substrate by sampling ca. $1 \mathrm{~kg}$ of the sediment and sieving the substrate in the laboratory, using mesh sizes of $20 \mathrm{~mm}, 5 \mathrm{~mm}, 2 \mathrm{~mm}, 0.5 \mathrm{~mm}, 0.1 \mathrm{~mm}$, and $0.063 \mathrm{~mm}$. I then plotted relative sediment mass against grain size in a double-logarithmic graph in order to determine mean grain size. I estimated the density of submerged vegetation and the extent of algal cover of stones and plants by counting, with $0 \%$ indicating no vegetation or algae and $100 \%$ representing extremely dense occurrence of submerged plants or algae.

Environmental factors were analyzed statistically by computing mean values and standard deviations for each mountain lake (Tab. 2), in order to assess the heterogeneity of physical and chemical water properties along the lake shores. I also performed statistical analysis on the samples as a whole, in order to assess the total range covered by the environmental factors.

\subsection{Multivariate statistical analyses}

In order to determine the relationships, if any, between the occurrence of aquatic molluscs and abiotic/biotic factors, I assembled two types of matrices (mollusc taxa abundance by sites and environmental variables by sites), to which I applied a multivariate gradient analysis. I followed the mathematical method of

Tab. 2. Results of environmental variable measurement at the studied lakes. Standard deviations in parentheses $(\mathrm{n}=10 \mathrm{for}$ each lake). For abbreviations see Table 1 and Figure 4.

\begin{tabular}{|c|c|c|c|c|c|c|c|c|c|c|c|c|c|c|c|c|}
\hline Factor & JS & $\mathbf{Z S}$ & HS & KBS & UBS & URS & $\mathbf{R S}$ & SCS & PS & STS & $\mathbf{K S}$ & SS & MIN & MAX & MEAN & SD \\
\hline ALT (m) & 1105 & 1339 & 1315 & 2170 & 1830 & 1760 & 2070 & 1450 & 1124 & 1080 & 1056 & 1120 & 1056 & 2170 & 1439 & 376 \\
\hline $\mathbf{T}\left({ }^{\circ} \mathrm{C}\right)$ & $\begin{array}{r}8.9 \\
(0.5)\end{array}$ & $\begin{array}{r}8.5 \\
(0.2)\end{array}$ & $\begin{array}{l}10.2 \\
(0.5)\end{array}$ & $\begin{array}{r}8.1 \\
(0.2)\end{array}$ & $\begin{array}{l}14.3 \\
(0.2)\end{array}$ & $\begin{array}{r}11.7 \\
(0.2)\end{array}$ & $\begin{array}{r}8.4 \\
(0.3)\end{array}$ & $\begin{array}{r}9.9 \\
(0.1)\end{array}$ & $\begin{array}{r}19.3 \\
(0.3)\end{array}$ & $\begin{array}{l}18.8 \\
(0.3)\end{array}$ & $\begin{array}{l}19.6 \\
(0.1)\end{array}$ & $\begin{array}{l}17.6 \\
(0.3)\end{array}$ & 7.9 & 19.8 & 13.3 & 4.5 \\
\hline $\mathrm{O}_{2} \%$ & $\begin{array}{l}93.0 \\
(1.4)\end{array}$ & $\begin{array}{l}96.0 \\
(1.0)\end{array}$ & $\begin{array}{l}93.5 \\
(2.6)\end{array}$ & $\begin{array}{l}96.3 \\
(1.7)\end{array}$ & $\begin{array}{l}95.3 \\
(1.2)\end{array}$ & $\begin{array}{l}94.0 \\
(1.0)\end{array}$ & $\begin{array}{l}92.7 \\
(1.2)\end{array}$ & $\begin{array}{l}93.0 \\
(1.6)\end{array}$ & $\begin{array}{l}84.0 \\
(4.3)\end{array}$ & $\begin{array}{l}90.0 \\
(1.8)\end{array}$ & $\begin{array}{l}90.5 \\
(4.8)\end{array}$ & $\begin{array}{r}87.8 \\
(1.7)\end{array}$ & 78.0 & 98.0 & 91.6 & 4.4 \\
\hline PH & $\begin{array}{r}7.6 \\
(0.2)\end{array}$ & $\begin{array}{r}6.8 \\
(0.2)\end{array}$ & $\begin{array}{r}6.5 \\
(0.2)\end{array}$ & $\begin{array}{r}6.6 \\
(0.2)\end{array}$ & $\begin{array}{r}6.9 \\
(0.2)\end{array}$ & $\begin{array}{r}6.8 \\
(0.2)\end{array}$ & $\begin{array}{r}7.4 \\
(0.3)\end{array}$ & $\begin{array}{r}6.2 \\
(0.1)\end{array}$ & $\begin{array}{r}6.1 \\
(0.4)\end{array}$ & $\begin{array}{r}5.9 \\
(0.4)\end{array}$ & $\begin{array}{r}6.4 \\
(0.3)\end{array}$ & $\begin{array}{r}5.8 \\
(0.3)\end{array}$ & 5.5 & 7.8 & 6.5 & 0.6 \\
\hline TH $\left(\mathrm{mg} \mathrm{l}^{-1}\right)$ & $\begin{array}{r}2.6 \\
(0.2)\end{array}$ & $\begin{array}{r}2.0 \\
(0.3)\end{array}$ & $\begin{array}{r}2.8 \\
(0.1)\end{array}$ & $\begin{array}{r}3.5 \\
(0.2)\end{array}$ & $\begin{array}{r}3.0 \\
(0.7)\end{array}$ & $\begin{array}{r}2.8 \\
(0.1)\end{array}$ & $\begin{array}{r}2.5 \\
(0.3)\end{array}$ & $\begin{array}{r}1.6 \\
(0.7)\end{array}$ & $\begin{array}{r}1.2 \\
(0.1)\end{array}$ & $\begin{array}{r}1.4 \\
(0.1)\end{array}$ & $\begin{array}{r}1.2 \\
(0.1)\end{array}$ & $\begin{array}{r}1.4 \\
(0.1)\end{array}$ & 1.0 & 3.8 & 2.1 & 0.8 \\
\hline $\mathrm{EC}\left(\mu \mathrm{S} \mathrm{cm} \mathbf{c m}^{-1}\right)$ & $\begin{array}{r}112.5 \\
(12.4)\end{array}$ & $\begin{array}{l}88.3 \\
(6.1)\end{array}$ & $\begin{array}{l}85.0 \\
(9.3)\end{array}$ & $\begin{array}{r}66.8 \\
(11.5)\end{array}$ & $\begin{array}{r}112.0 \\
(6.1)\end{array}$ & $\begin{array}{r}105.7 \\
(3.5)\end{array}$ & $\begin{array}{l}68.7 \\
(9.5)\end{array}$ & $\begin{array}{r}76.0 \\
(10.6)\end{array}$ & $\begin{array}{r}105.0 \\
(21.1)\end{array}$ & $\begin{array}{r}99.3 \\
(9.0)\end{array}$ & $\begin{array}{r}77.5 \\
(10.4)\end{array}$ & $\begin{array}{r}128.8 \\
(3.6)\end{array}$ & 56.0 & 158.0 & 98.1 & 25.3 \\
\hline $\mathbf{N}\left(\mathrm{mg} \mathrm{l}^{-1}\right)$ & $\begin{array}{r}2.9 \\
(1.5)\end{array}$ & $\begin{array}{r}1.9 \\
(0.9)\end{array}$ & $\begin{array}{r}1.6 \\
(1.3)\end{array}$ & $\begin{array}{r}1.7 \\
(0.5)\end{array}$ & $\begin{array}{r}1.3 \\
(0.2)\end{array}$ & $\begin{array}{r}0.7 \\
(0.3)\end{array}$ & $\begin{array}{r}0.9 \\
(0.7)\end{array}$ & $\begin{array}{r}1.3 \\
(0.1)\end{array}$ & $\begin{array}{r}3.5 \\
(0.3)\end{array}$ & $\begin{array}{r}3.6 \\
(0.2)\end{array}$ & $\begin{array}{r}3.5 \\
(0.3)\end{array}$ & $\begin{array}{r}3.5 \\
(0.2)\end{array}$ & 0.2 & 4.6 & 2.2 & 1.3 \\
\hline $\mathrm{BOD}_{5}\left(\mathrm{mg} \mathrm{l}^{-1}\right)$ & $\begin{array}{r}2.1 \\
(0.4)\end{array}$ & $\begin{array}{r}1.3 \\
(1.0)\end{array}$ & $\begin{array}{r}1.9 \\
(0.3)\end{array}$ & $\begin{array}{r}0.8 \\
(0.6)\end{array}$ & $\begin{array}{r}1.9 \\
(0.7)\end{array}$ & $\begin{array}{r}1.5 \\
(0.5)\end{array}$ & $\begin{array}{r}1.3 \\
(0.5)\end{array}$ & $\begin{array}{r}2,2 \\
(0.9)\end{array}$ & $\begin{array}{r}3.8 \\
(0.3)\end{array}$ & $\begin{array}{r}3.2 \\
(0.6)\end{array}$ & $\begin{array}{r}3.2 \\
(0.2)\end{array}$ & $\begin{array}{r}3.2 \\
(0.3)\end{array}$ & 0.3 & 4.1 & 2.2 & 1.0 \\
\hline S $(\%)$ & $\begin{array}{r}45.0 \\
(23.8)\end{array}$ & $\begin{array}{l}48.3 \\
(7.6)\end{array}$ & $\begin{array}{r}20.0 \\
(14.1)\end{array}$ & $\begin{array}{l}17.5 \\
(5.0)\end{array}$ & $\begin{array}{r}0.0 \\
(0.0)\end{array}$ & $\begin{array}{r}3.3 \\
(5.8)\end{array}$ & $\begin{array}{r}63.3 \\
(15.3)\end{array}$ & $\begin{array}{l}47.5 \\
(9.6)\end{array}$ & $\begin{array}{l}30.0 \\
(8.2)\end{array}$ & $\begin{array}{r}35.0 \\
(12.9)\end{array}$ & $\begin{array}{r}15.0 \\
(5.8)\end{array}$ & $\begin{array}{r}60.0 \\
(8.2)\end{array}$ & 0,0 & 80.0 & 30.4 & 22.1 \\
\hline SV $(\%)$ & $\begin{array}{r}44.5 \\
(26.1)\end{array}$ & $\begin{array}{l}61.7 \\
(2.9)\end{array}$ & $\begin{array}{l}37.1 \\
(8.6)\end{array}$ & $\begin{array}{l}13.1 \\
(2.4)\end{array}$ & $\begin{array}{r}0.0 \\
(0.0)\end{array}$ & $\begin{array}{r}3.3 \\
(3.8)\end{array}$ & $\begin{array}{l}15.8 \\
(3.8)\end{array}$ & $\begin{array}{r}69,4 \\
(10.9)\end{array}$ & $\begin{array}{l}43.8 \\
(6.6)\end{array}$ & $\begin{array}{l}77.5 \\
(6.5)\end{array}$ & $\begin{array}{r}80.0 \\
(10.2)\end{array}$ & $\begin{array}{r}66.3 \\
(7.8)\end{array}$ & 0.0 & 90.0 & 45.0 & 27.5 \\
\hline ALG (\%) & $\begin{array}{r}31.3 \\
(12.1)\end{array}$ & $\begin{array}{r}33.3 \\
(14.4)\end{array}$ & $\begin{array}{r}18.8 \\
(23.9)\end{array}$ & $\begin{array}{r}0.0 \\
(0.0)\end{array}$ & $\begin{array}{r}0.0 \\
(0.0)\end{array}$ & $\begin{array}{r}0.0 \\
(0.0)\end{array}$ & $\begin{array}{r}8.3 \\
(14.4)\end{array}$ & $\begin{array}{r}56.3 \\
(12.3)\end{array}$ & $\begin{array}{r}25.0 \\
(0.0)\end{array}$ & $\begin{array}{r}68.8 \\
(12.5)\end{array}$ & $\begin{array}{r}59.8 \\
(10.7)\end{array}$ & $\begin{array}{r}72.5 \\
(15.3)\end{array}$ & 0.0 & 75.0 & 35.0 & 27.5 \\
\hline SUB (mm) & $\begin{array}{r}2.5 \\
(0.4)\end{array}$ & $\begin{array}{r}1.2 \\
(0.2)\end{array}$ & $\begin{array}{r}5.6 \\
(1.5)\end{array}$ & $\begin{array}{l}10.5 \\
(7.8)\end{array}$ & $\begin{array}{r}22.0 \\
(10.7)\end{array}$ & $\begin{array}{l}14.0 \\
(3.1)\end{array}$ & $\begin{array}{r}5.8 \\
(2.9)\end{array}$ & $\begin{array}{r}2.4 \\
(0.8)\end{array}$ & $\begin{array}{r}4.1 \\
(1.4)\end{array}$ & $\begin{array}{r}3.5 \\
(1.1)\end{array}$ & $\begin{array}{r}4.5 \\
(1.7)\end{array}$ & $\begin{array}{r}6.5 \\
(3.2)\end{array}$ & 1.2 & 22.0 & 6.1 & 5.4 \\
\hline
\end{tabular}


Canonical Correspondence Analysis (CCA; Ter Braak 1986, 1988; Palmer 1993; Ter Braak \& Verdonschot 1995), which uses a combination of ordination and regression techniques to evaluate the response of animal community compositions to environmental gradients. By applying this method, I assumed that animals occuring in a specific range of habitats, are most abundant around an optimum, and community composition changes along a gradient. Following convention, I plotted the results of CCA into graphs, with species represented as points and environmental factors represented by arrows starting from the origin. Goodness of fit for the CCA model used in this study was obtained using the Monte Carlo permutation test outlined by Verdonshot and Ter Braak (1994). All modelling was done with the computer program Multi-Variate Statistical Package (MVSP, version 3.1). Values for species abundance were log-transformed, resulting in a better approximation to the normal distribution. While a down-weighting procedure for rare mollusc species was applied, forward selection was not possible within MVSP.

\section{RESULTS}

\subsection{Environmental variables}

Water temperature was remarkably heterogeneous, ranging from $7.9^{\circ} \mathrm{C}$ to $19.8^{\circ} \mathrm{C}$, with a mean temperature of $13.3{ }^{\circ} \mathrm{C}$ (Tab. 2). Oxygen saturation varied between $78 \%$ and $98 \%$, indicating that the sample sites had a slight under-saturation of $\mathrm{O}_{2}$ due to, perhaps, metabolic processes or decomposition. Water $\mathrm{pH}$ ranged from 5.5 to 7.8. Total hardness was quite low among the lakes, with a maximum value of $3.8 \mathrm{mg} \mathrm{l}^{-1}$ and a mean value of $2.1 \mathrm{mg} \mathrm{l}^{-1}$. Like total hardness, conductivity was generally low in all of the study lakes (mean value: 98.1 $\mu \mathrm{S} \mathrm{cm}{ }^{-1}$ ), which is characteristic for lakes situated in the silicate rocks of the Central Alps.

Nitrate and $\mathrm{BOD}_{5}$ of the water showed a somewhat similar behaviour, with a wide range of values and a
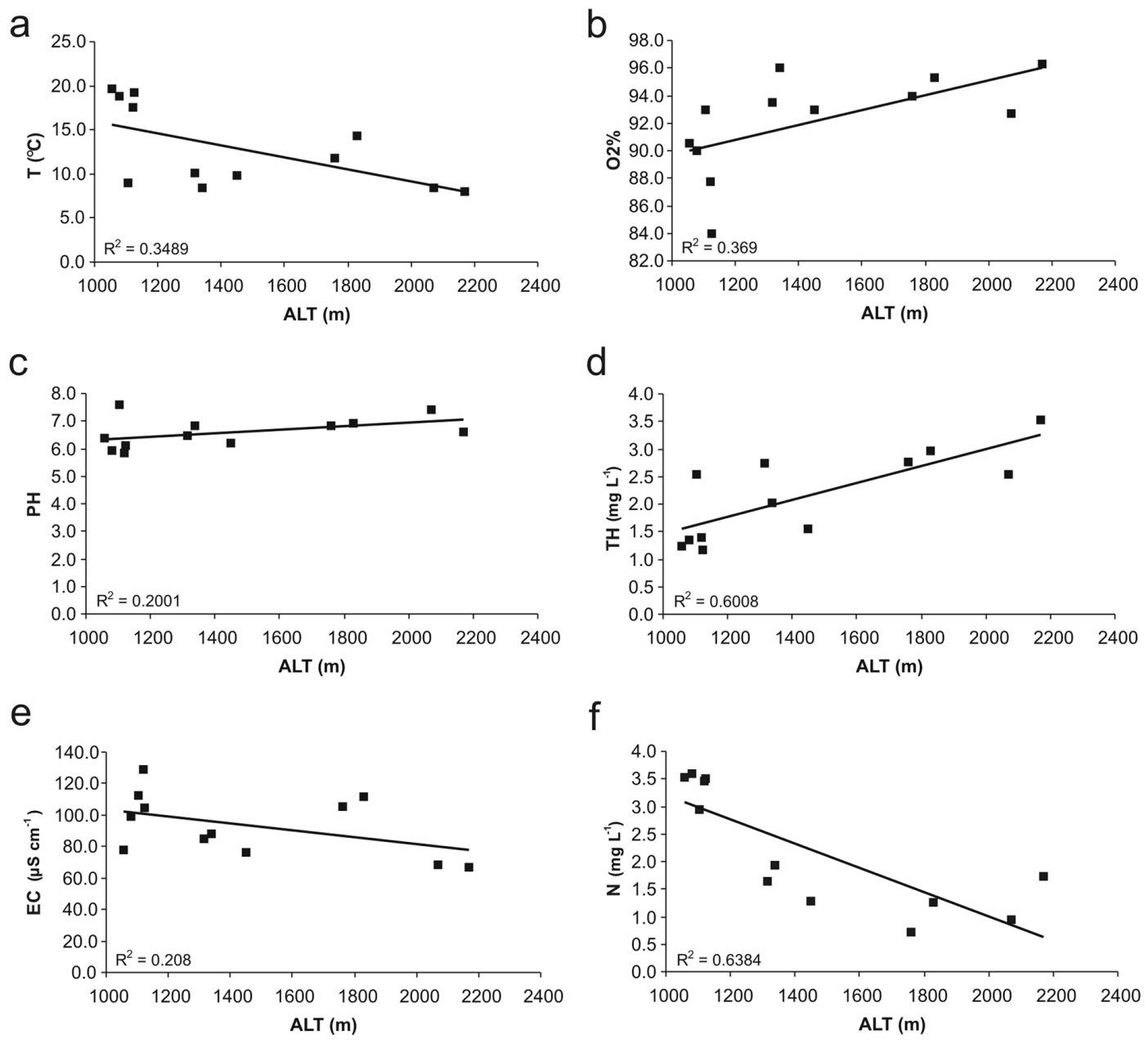

Fig. 2. Relationships between environmental variables and altitude: Temperature (a), oxygen saturation (b), pH (c), total hardness (d), conductivity (e), and nitrate (f). 
mean of approximately $2 \mathrm{mg} \mathrm{l}^{-1}$ (Tab. 2). With respect to shading of the lake shore, there was high fluctuation among the studied lakes, with values ranging from $0 \%$ to $80 \%$, and a mean value of $30.4 \%$ (Tab. 2). Submerged vegetation and algal cover of the sediment showed similar mean values (45\% and $35 \%$ ) and standard deviations (27.5\%) in all studied lakes. Mean grain size of the bottom substrate varied between $1.2 \mathrm{~mm}$, indicating sandy substrate, and $22 \mathrm{~mm}$, suggesting a stony bottom.

In addition to varying widely between lakes, in certain lakes, the measured abiotic and biotic parameters also varied widely between sample sites. In general, lakes that were highly influenced by terrestrial and/or aquatic vegetation showed a higher variation in measurements between sample points (e.g. Jägersee), than lakes characterized by very sparse vegetation (e.g. Kratzenbergsee; Tab. 2). Linear regression analysis also showed that variables measured at the sample points
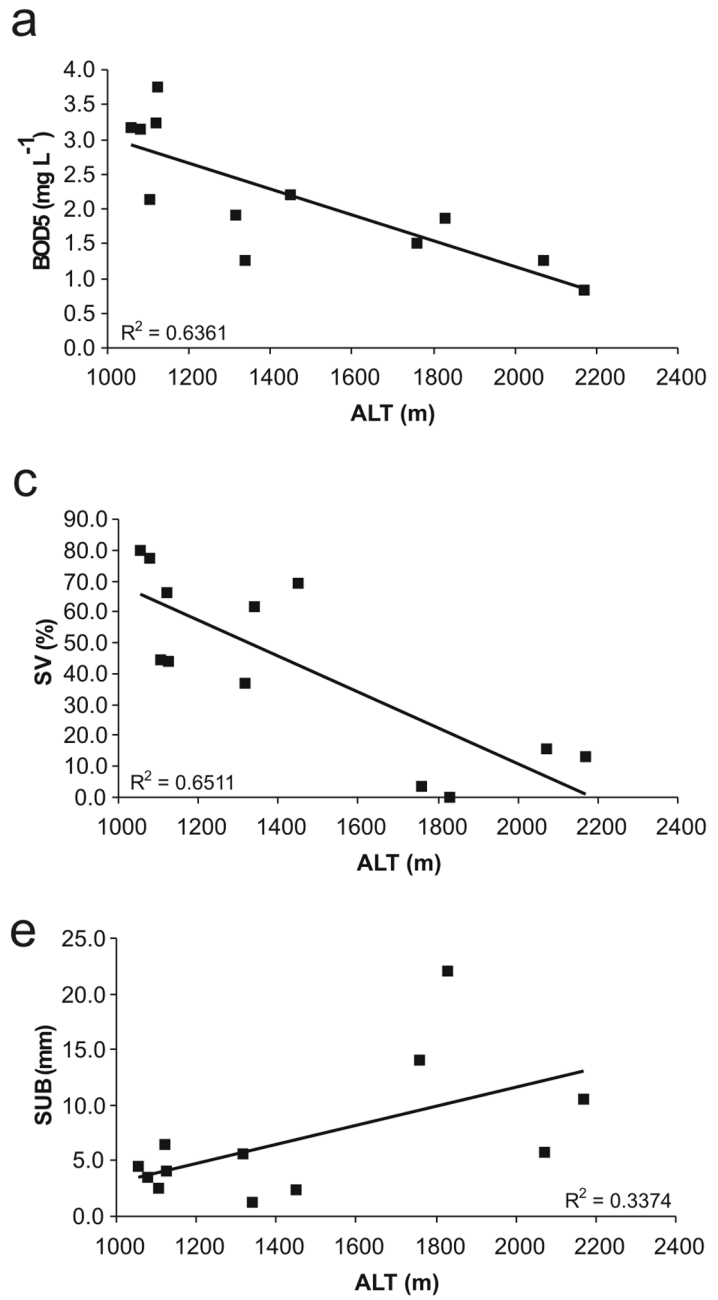

changed significantly with altitude (Figs 2 and 3). While water temperature, $\mathrm{BOD}_{5}$, nitrate content, submerged vegetation and algal cover decreased with increasing altitude, oxygen saturation, total hardness, and mean grain size of the bottom substrate, shading, water $\mathrm{pH}$, and conductivity did not exhibit a significant dependence upon altitude.

\subsection{Mollusc diversity and abundances}

The highest number of freshwater mollusc species, namely 7 gastropod and 5 bivalve taxa, was recorded at Jägersee, followed by Schödersee with a total of 8 species and Seetalersee with 7 species (Tab. 3). The lowest species diversity occurred at Kratzenbergsee, where I recorded only the pill clam Pisidium casertanum (Poli 1791) and the pulmonate mud snail Galba truncatula (O. F. Müller 1774). Over all of the lakes, I recorded a total of 13 mollusc species (8 gastropods and 5 bivalves)

b
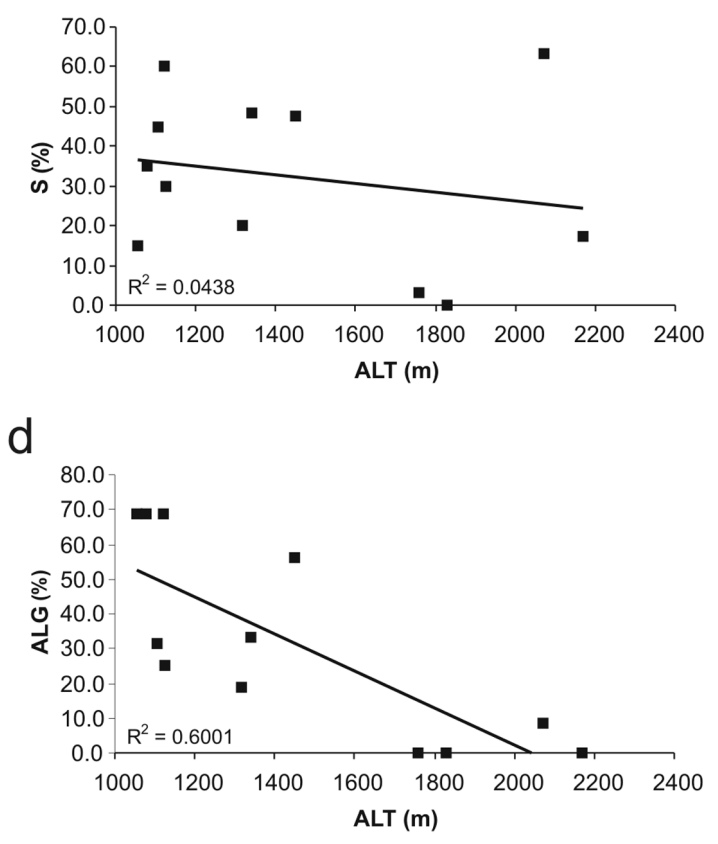

Fig. 3. Relationships between environmental variables and altitude: Biological oxygen demand (a), shading (b), submerged vegetation (c), cover algal (d), and substrate grain size (e). 
in the Alpine water bodies, with the highest abundances occurring for P. casertanum, G. truncatula, Radix balthica (Linnaeus 1758), and Pisidium subtruncatum Malm 1855. Lowest individual numbers were found for Pisidium nitidum Jenyns 1832, Musculium lacustre (O. F. Müller 1774), Acroloxus lacustris (Linnaeus 1758), and Planorbis planorbis (Linnaeus 1758), each occurring with an average population density of less than 1 ind. $\mathrm{m}^{-2}$. Generally, there were significant differences in species number and specific abundances among and within study lakes (Tab. 3). The most remarkable differences were between water bodies of the montane vegetation zone and the subalpine vegetation zone. Lakes from the higher Alpine level had lower average number of species, and showed a sharp decrease in the population density of molluscs, for example $P$. casertanum occurred at a density of $19.3 \pm 5.1$ ind. $\mathrm{m}^{-2}$ in the Seetalersee, but fell to $3.5+4.1$ ind. $\mathrm{m}^{-2}$ in the Kratzenbergsee.

As the moderately high standard deviations in Table 3 indicate, species abundances also exhibited significant variation among the sample sites of each lake. This finding underscores the heterogeneous distribution of most mollusc species along the lake shore, which, in most cases, was linked to variable distribution of terrestrial and submerged vegetation.

\subsection{Canonical Correspondence Analysis}

I performed multivariate analysis on both the malacological and physico-chemical data set in order (1) to elucidate possible relationships between the spatial distribution of mollusc species and environmental conditions and (2) to test a classification of the sample sites according to the 12 environmental variables measured (Fig. 4). The first two axes accounted for $24 \%$ of the variance, with axis 1 (13.5\% of the variance) representing water $\mathrm{pH}$, shading, and oxygen saturation against conductivity. Axis 2 (10.5\% of the variance) consisted mainly of algal cover, submerged vegetation, and nitrate content against total hardness. Except for water temperature, which had to be excluded from further consideration, possible multi-colinearity among environmental variables was insignificant, because respective variance inflation factors ranged from 1.22 (shading) to 3.75 (altitude).

In the projection of mollusc species together with the environmental variables, most of the species are clustered in the third quadrant of the graph (Fig. 4 a). This suggests that $P$. planorbis, Anisus spirorbis (Linnaeus 1758), and M. lacustre showed an enhanced affinity for increased amounts of submerged vegetation, while $A$. lacustris preferred higher values of oxygen saturation.

Tab. 3. Results of mollusc recording and counting at the studied lakes (ind. $\mathrm{m}^{-2}$ ). Standard deviations in parentheses $(\mathrm{n}=10$ for each lake). For abbreviations see Table 1 and Figure 4.

\begin{tabular}{|c|c|c|c|c|c|c|c|c|c|c|c|c|c|c|c|c|}
\hline Species & JS & $\mathbf{Z S}$ & HS & KBS & UBS & URS & RS & SCS & PS & STS & KS & SS & MIN & MAX & EAN & SD \\
\hline \multirow[t]{2}{*}{ Rl } & 3.3 & 5.0 & 1.3 & 0.0 & 0.0 & 0.0 & 0.0 & 6.8 & 3.8 & 1.8 & 5.0 & 6.3 & 0.0 & 9.0 & 2.8 & 3.1 \\
\hline & (1.5) & (3.6) & (1.9) & $(0.0)$ & $(0.0)$ & $(0.0)$ & $(0.0)$ & (2.1) & (3.9) & $(2.1)$ & $(2.2)$ & (3.5) & & & & \\
\hline \multirow[t]{2}{*}{$\mathbf{R b}$} & 0.0 & 3.7 & 5.5 & 0.0 & 0.0 & 0.0 & 6.3 & 4.5 & 1.5 & 5.0 & 10.0 & 9.8 & 0.0 & 17.0 & 4.5 & 5.0 \\
\hline & $(0.0)$ & (3.2) & $(4.0)$ & $(0.0)$ & $(0.0)$ & $(0.0)$ & $(2.1)$ & (2.4) & $(3.0)$ & (6.6) & (7.4) & (2.6) & & & & \\
\hline \multirow[t]{2}{*}{ Gt } & 6.0 & 10.7 & 0.0 & 5.0 & 0.0 & 0.0 & 8.7 & 0.0 & 13.3 & 7.5 & 13.0 & 10.3 & 0.0 & 23.0 & 6.5 & 5.7 \\
\hline & $(2.2)$ & (1.5) & $(0.0)$ & (6.6) & $(0.0)$ & $(0.0)$ & (2.1) & $(0.0)$ & (7.4) & (3.4) & (2.2) & (2.9) & & & & \\
\hline \multirow[t]{2}{*}{ As } & 8.0 & 0.0 & 0.0 & 0.0 & 0.0 & 0.0 & 0.0 & 8.3 & 0.0 & 0.0 & 0.0 & 0.0 & 0.0 & 11.0 & 1.4 & 3.1 \\
\hline & $(2.2)$ & $(0.0)$ & $(0.0)$ & $(0.0)$ & $(0.0)$ & $(0.0)$ & $(0.0)$ & (1.5) & $(0.0)$ & $(0.0)$ & $(0.0)$ & $(0.0)$ & & & & \\
\hline \multirow[t]{2}{*}{ Al } & 6.0 & 0.0 & 0.0 & 0.0 & 0.0 & 0.0 & 0.0 & 3.8 & 0.0 & 1.8 & 1.5 & 0.0 & 0.0 & 10.0 & 1.1 & 2.5 \\
\hline & (3.7) & $(0.0)$ & $(0.0)$ & $(0.0)$ & $(0.0)$ & $(0.0)$ & $(0.0)$ & (4.3) & $(0.0)$ & (2.4) & (2.4) & $(0.0)$ & & & & \\
\hline \multirow[t]{2}{*}{ Bc } & 4.0 & 0.0 & 0.0 & 0.0 & 0.0 & 0.0 & 0.0 & 6.5 & 0.0 & 9.0 & 0.0 & 0.0 & 0.0 & 12.0 & 1.6 & 3.2 \\
\hline & (2.4) & $(0.0)$ & $(0.0)$ & $(0.0)$ & $(0.0)$ & $(0.0)$ & $(0.0)$ & (1.3) & $(0.0)$ & (2.9) & $(0.0)$ & $(0.0)$ & & & & \\
\hline \multirow[t]{2}{*}{$\mathbf{P p}$} & 8.8 & 0.0 & 0.0 & 0.0 & 0.0 & 0.0 & 0.0 & 0.0 & 0.0 & 0.0 & 0.0 & 0.0 & 0.0 & 11.0 & 0.7 & 2.5 \\
\hline & $(2.2)$ & $(0.0)$ & $(0.0)$ & $(0.0)$ & $(0.0)$ & $(0.0)$ & $(0.0)$ & $(0.0)$ & $(0.0)$ & $(0.0)$ & $(0.0)$ & $(0.0)$ & & & & \\
\hline \multirow[t]{2}{*}{ Acl } & 4.5 & 3.0 & 0.0 & 0.0 & 0.0 & 0.0 & 0.0 & 0.0 & 0.0 & 0.0 & 0.0 & 0.0 & 0.0 & 9.0 & 0.6 & 1.6 \\
\hline & (3.1) & $(1.0)$ & $(0.0)$ & $(0.0)$ & $(0.0)$ & $(0.0)$ & $(0.0)$ & $(0.0)$ & $(0.0)$ & $(0.0)$ & $(0.0)$ & $(0.0)$ & & & & \\
\hline \multirow[t]{2}{*}{ Ml } & 3.3 & 0.0 & 0.0 & 0.0 & 0.0 & 0.0 & 0.0 & 5.3 & 0.0 & 0.0 & 0.0 & 0.0 & 0.0 & 8.0 & 0.7 & 2.0 \\
\hline & (3.9) & $(0.0)$ & $(0.0)$ & $(0.0)$ & $(0.0)$ & $(0.0)$ & $(0.0)$ & (1.7) & $(0.0)$ & $(0.0)$ & $(0.0)$ & $(0.0)$ & & & & \\
\hline \multirow[t]{2}{*}{ Pc } & 8.0 & 12.7 & 3.8 & 3.5 & 0.0 & 0.0 & 7.3 & 18.5 & 11.0 & 19.3 & 11.3 & 8.0 & 0.0 & 24.0 & 9.5 & 7.5 \\
\hline & (3.7) & (6.4) & (4.8) & $(4.1)$ & $(0.0)$ & $(0.0)$ & $(8.1)$ & (2.6) & $(3.5)$ & $(5.1)$ & (4.6) & (5.4) & & & & \\
\hline \multirow[t]{2}{*}{ Ps } & 8.0 & 8.7 & 5.8 & 0.0 & 0.0 & 0.0 & 6.0 & 9.0 & 0.0 & 0.0 & 0.0 & 0.0 & 0.0 & 15.0 & 2.8 & 4.2 \\
\hline & (2.9) & (5.5) & (1.7) & $(0.0)$ & $(0.0)$ & $(0.0)$ & (2.6) & (4.1) & $(0.0)$ & $(0.0)$ & $(0.0)$ & $(0.0)$ & & & & \\
\hline \multirow[t]{2}{*}{ Po } & 3.3 & 0.0 & 0.0 & 0.0 & 0.0 & 0.0 & 0.0 & 0.0 & 0.0 & 8.0 & 6.3 & 0.0 & 0.0 & 12.0 & 2.0 & 3.4 \\
\hline & (1.3) & $(0.0)$ & $(0.0)$ & $(0.0)$ & $(0.0)$ & $(0.0)$ & $(0.0)$ & $(0.0)$ & $(0.0)$ & $(4.2)$ & (3.4) & $(0.0)$ & & & & \\
\hline \multirow[t]{2}{*}{ Pn } & 5.3 & 0.0 & 0.0 & 0.0 & 0.0 & 0.0 & 0.0 & 0.0 & 0.0 & 0.0 & 0.0 & 0.0 & 0.0 & 8.0 & 0.4 & 1.6 \\
\hline & (2.6) & $(0.0)$ & $(0.0)$ & $(0.0)$ & $(0.0)$ & $(0.0)$ & $(0.0)$ & $(0.0)$ & $(0.0)$ & $(0.0)$ & $(0.0)$ & $(0.0)$ & & & & \\
\hline
\end{tabular}



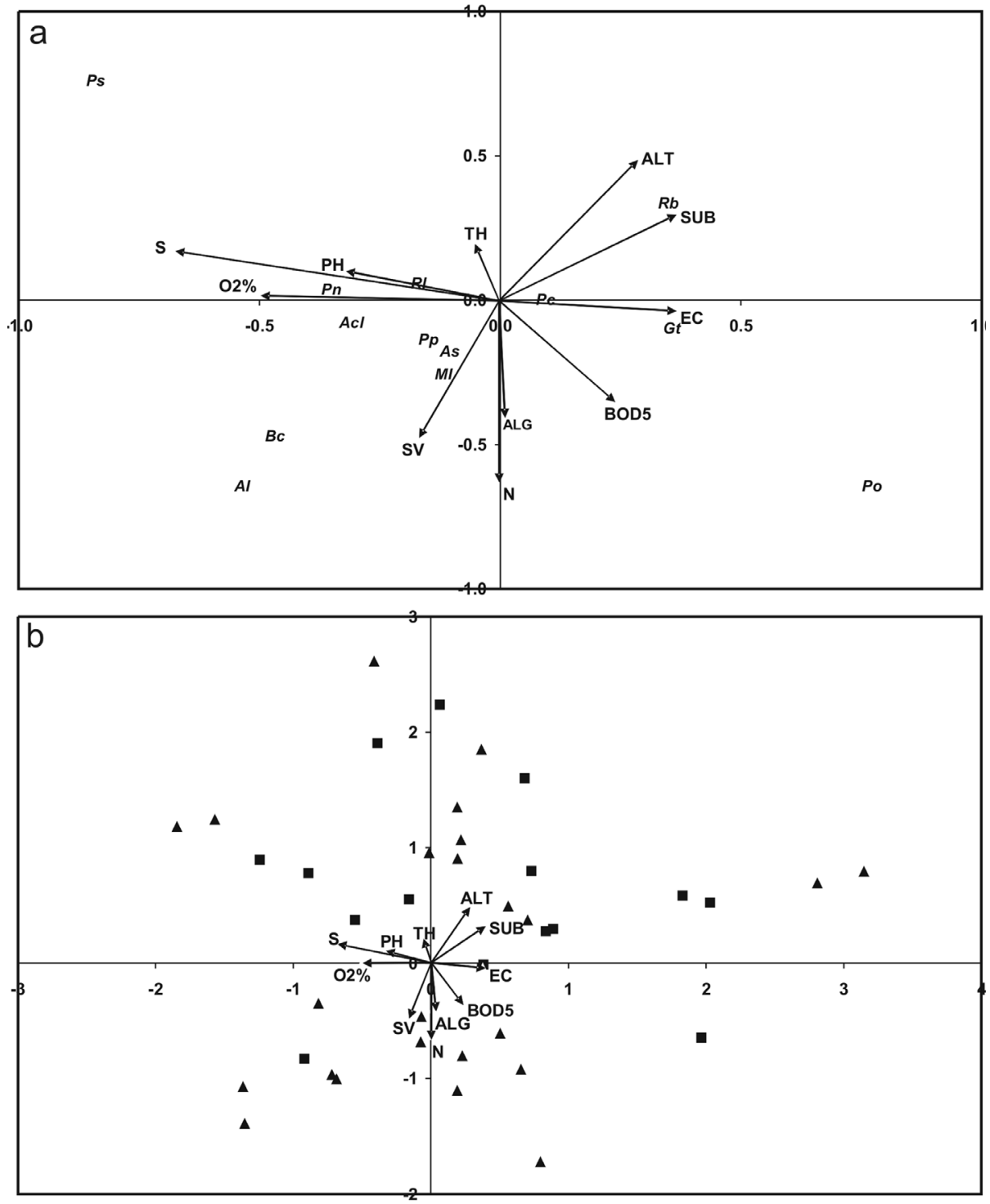

Fig. 4. Results of multivariate statistics. a) Relationships between environmental variables (vectors) and species (Abbreviations: Acl...Acroloxus lacustris, Al...Anisus leucostoma, As...Anisus spirorbis, Bc...Bathyomphalus contortus, Gt...Galba truncatula, Ml...Musculium lacustre, Pc...Pisidium casertanum, Pn...P. nitidum, Po...P. obtusale, Pp...Planorbis planorbis, Ps...Pisidium subtruncatum, Rb...Radix balthica, Rl...R. labiata; ALG... algal cover, ALT....altitude, BOD5...biological oxygen demand, EC...conductivity, N...nitrate content, $\mathrm{O}_{2} \%$...oxygen saturation, PH... water $\mathrm{pH}, \mathrm{S}$... shading, SUB ... substrate grain size, SV ... submerged vegetation, TH...total hardness). b) Relationships between environmental variables (vectors) and sampling sites: (see text).

While Bathyomphalus contortus (Linnaeus 1758) and Anisus leucostoma (Millet 1813) did not exhibit a strong dependence on the variables defining the quadrant, their position in the graph indicates that they preferentially occurred at sites with higher values of the measured biotic and abiotic parameters. In the second quadrant of the graph, 3 species were positioned, indicating that $P$. nitidum and, to a minor extent, Radix labiata (Rossmaessler 1835) have an affinity for higher values of oxygen saturation, shading, and water $\mathrm{pH}$. The position of $P$. subtruncatum suggested a tolerance of the variables defining this quadrant. $R$. balthica and P. casertanum are situated in the first quadrant of the graph, indicating that the gastropod had an affinity for higher altitudes and larger grain-sizes of substrate, while the bivalve preferred medium substrate grain-size and conductivity. $G$. truncatula and Pisidium obtusale (Lamarck 1818) appear in the fourth quadrant of the graph, with the mud snail exhibiting a strong affinity for high conductivity while the pill clam is characterized by a remarkable independence of the environmental variables.

Regarding a possible relationship between sampling sites and environmental variables, sampling points in the montane vegetation zone (solid triangles) exhibited 
a very irregular distribution with most points falling to the right of axis 2 (Fig. 4 b). Sampling points in the subalpine vegetation zone (solid squares) chiefly plotted in quadrants 1 and 2 of the graph. Most points did not show a significant correlation with the environmental variables, but, more generally, subalpine lakes were characterized by higher values for substrate grain size and total hardness, whereas montane water bodies exhibited higher values for submerged vegetation, nitrate content, algae, and $\mathrm{BOD}_{5}$. Based on these findings, montane lakes may experience a higher influence of terrestrial and aquatic vegetation and have a substrate that consists of fine particles, mixed with plant components. Subalpine lakes, on the other hand, are only sparsely affected by terrestrial and aquatic vegetation, and have a bottom substrate that mainly consists of stones and larger blocks that are only partly crushed by transport processes.

\section{DISCUSSION}

As demonstrated by Turner et al. (1998) for the Swiss Alps, both species number and abundance of freshwater molluscs decline remarkably with increasing altitude. According to the authors, malacological diversity at $2000 \mathrm{~m}$ (the subalpine vegetation level) declines to a total of 15 species, while at $3000 \mathrm{~m}$ no mollusc species have yet been found. In the same altitude range, species abundances decrease from up to 100 ind. $\mathrm{m}^{-2}$ to zero ind. $\mathrm{m}^{-2}$. The results of the study presented here greatly correspond with the findings of Turner et al. (1998) for the Western Alps. As such, according to this field study, subalpine water bodies have a significantly reduced malacofauna as compared to lakes in the montane level. This investigation underscores that the dependence of mollusc distribution upon altitude results from changing environmental conditions.

It is well known that water bodies at high altitudes are dominated by generalist species (some pill clams and lymnaeids), while, on the other hand, montane lakes are also colonized by specialists when levels of submerged vegetation and nutrients are high (Glöer \& Meier-Brook 2003). During this investigation, within the group of aquatic snails, G. truncatula and $R$. labiata were collected most frequently (Tab. 3). At least one of these two species occurred in all of the lakes colonized by aquatic molluscs. According to Turner et al. (1998), Glöer (2002), and Glöer \& Meier-Brook (2003), G. truncatula are a widely distributed species, and particularly colonize the shores of larger lakes and are more or less independent of $\mathrm{CaCO}_{3}$ concentration. Turner et al. (1998) describe this gastropod species as a ubiquist, which has already reached the upper-Alpine $(2800 \mathrm{~m})$ waters in Switzerland. A very similar distribution is reported for R. labiata, which, at the moment, is found at a maximum altitude of $2700 \mathrm{~m}$. The third detected species of Lymnaeidae is $R$. balthica, which prefers small ponds that are rich in macrophytes (Sturm 1999; Glöer \& Meier-Brook 2003; Jaeckel 2004), but also occurs in fast flowing brooks and rivers (Patzner 1996). According to Turner et al. (1998), R. balthica has already reached altitudes of $2500 \mathrm{~m}$ in Switzerland.

All species of Planorbidae recorded in this study preferred lakes in the montane vegetation zone. According to previous publications (e.g. Sturm 1998; Glöer \& Meier-Brook 2003), A. leucostoma, A. spirorbis, B. contortus, and $P$. planorbis mainly colonize small ponds with thick vegetation or bays within rivers and brooks, and can reach high population densities. For A. leucostoma, Turner et al. (1998) describe a distribution up to $2250 \mathrm{~m}$ in the Swiss Alps, while the other species have been found at maximum altitudes of about $1500 \mathrm{~m}$. According to this contribution, the occurrence of $A$. lacustris is limited to a maximum altitude of $1300 \mathrm{~m}$ and is characterized by low frequencies. This gastropod is mainly found on stalks and leaves of plants, but can also colonize the surface of stones covered with layers of algae.

Regarding the bivalves, I only recorded species of the family Sphaeriidae. A rather homogeneous distribution throughout the colonized lakes was observed for $P$. casertanum and, with some exceptions, also for $P$. subtruncatum. Both pill clams are widely distributed in Middle Europe, being extremely tolerant of any changes in environmental conditions (i.e. temperature, $\mathrm{pH}$, $\mathrm{CaCO}_{3}$ content), and, in many cases, are characterized by high abundances (e.g. Kuiper 1974; Meier-Brook 1975; Falkner 1990; Glöer \& Meier-Brook 2003). Turner et al. (1998) describe an occurrence of P. casertanum, in Switzerland, up to $2750 \mathrm{~m}$ (Rifflsee at Zermatt), whereas $P$. subtruncatum was limited to a maximum altitude of $2000 \mathrm{~m}$. With respect to $P$. obtusale and $P$. nitidum, ecological requirements outlined in the literature are different to those of $P$. casertanum (Meier-Brook 1975; Glöer \& Meier-Brook 2003). The occurrence of $M$. lacustre is limited to two lakes with high vegetation density (Jägersee, Schödersee). In Switzerland, the maximum altitude reached by this species is $1350 \mathrm{~m}$ (Turner et al. 1998). Regarding its ecology, M. lacustre mainly prefers shallow ponds and slowly flowing rivers, thereby often acting as a pioneer species that colonizes a habitat before its competitors (e.g. Sturm 1999).

As documented in the results section, the two lakes dammed for electricity production (Lower Bockhartsee, Lower Rotgüldensee) do not bear any malacofauna. Besides several other parameters, the most reasonable cause for this phenomenon are the periodic fluctuations of the water level that are typical for such lakes. Due to significant water level fluctuations, the shore vegetation is very sparse and cannot provide enough micro-habitats for molluscs. Additionally, the ground of both lakes is mainly composed of medium- to coarse-grained mineral substrate and therefore does not provide optimum con- 
ditions for gastropods and bivalves. As documented in previous studies (e.g. Kuiper 1974), storage lakes are rarely colonized by molluscs.

Based on the results of the present study, colonization of Alpine waters by aquatic molluscs depends highly upon the ecological demands of single gastropod and bivalve species, with generalistic species penetrating to higher biotopes than specialists. However, further investigations seem necessary to document this colonization process and to verify the present findings.

\section{REFERENCES}

Falkner, G. 1990. Binnenmollusken. In: Fechter R. \& G. Falkner (Ed.), Weichtiere. Europäische Meeres- und Binnenmollusken. Kosmos-Verlag, München: 112-120.

Frank, C. 1992. Malakologisches aus dem Ostalpenraum. Linzer biol. Beitr., 24: 383-662.

Frank, C. 1996. Malakologisches aus dem Ostalpenraum unter besonderer Berücksichtigung südlicher Gebiete 19921995. Linzer biol. Beitr., 28: 75-164.

Glöer, P. 2002. Die Süßwassergastropoden Nord- und Mitteleuropas. Bestimmungsschlïssel, Lebensweise, Verbreitung. ConchBooks, Hackenheim: 327 pp.

Glöer, P. \& C. Meier-Brook. 2003. Süsswassermollusken. DJN, Hamburg: $138 \mathrm{pp}$.

Hosmer, D.W. \& S. Lemeshow. 2000. Applied Logistic Regression. Wiley \& Sons, New York: 392 pp.

Jaeckel, S.H. 2004. Die Schlammschnecken unserer Gewässer. Westarp, Leipzig: $30 \mathrm{pp}$.

Köck, G., R. Hofer \& S. Wögrath-Sommaruga. 1995. Accumulation of trace metals $(\mathrm{Cd}, \mathrm{Pb}, \mathrm{Cu}, \mathrm{Zn})$ in Arctic char (Salvelinus alpinus) from oligotrophic Alpine lakes: relation to alkalinity. Can. J. Fish. Aquat. Sci., 52: 2367-2376.

Kuiper, J.G.J. 1974. Die Pisidien der Hochalpengewässer. Arch. Mollkde., 104: 1-27.

Lami, A. \& A. Boggero. 2006. Ecology of high altitude aquatic systems in the Alps. Hydrobiologia, 562: $246 \mathrm{pp}$.

Meier-Brook, C. 1975. Der ökologische Indikatorwert mitteleuropäischer Pisidium-Arten (Mollusca, Eulamellibranchiata). Eiszeit und Gegenwart, 25: 190-195.

Palmer, M.W. 1993. Putting things in even better order: The advantages of Canonical Correspondence Analysis. Ecology, 74: 2215-2230.

Patzner, R.A. 1994. Über das Sammeln heimischer Wassermollusken. BUFUS-Info, 14: 7-12.

Patzner, R.A. 1995. Wasserschnecken und Muscheln im Bundesland Salzburg. Stand zu Beginn einer landesweiten Kartierung. Nachrbl. Ersten Vorarlb. Malak. Ges., 3: 12-29.

Received: July 2007

Accepted: November 2007
Patzner, R.A. 1996. Die Neuseeländische Zwergdeckelschnecke Potamopyrgus antipodarum (Gray 1843) im Bundesland Salzburg. Linzer biol. Beitr., 28: 1153-1159.

Sperling, P. 1975. Zur Schneckenfauna des Lungaues (Land Salzburg, Österreich). Mitt. Dt. Malak. Ges., 2: 269-377.

Sommaruga, R. 2001. The role of solar UV radiation in the ecology of Alpine lakes. J. Photochem. Photobiol. B. Biol., 62: $35-42$.

Sommaruga, R., R. Psenner, E. Schafferer, K.A. Koinig \& S. Sommaruga-Wögrath. 1999. Dissolved organic carbon concentration and phytoplankton biomass in high- mountain lakes of the Austrian Alps: Potential effects of climatic warming on UV underwater attenuation. Arctic, Antarctic, and Alpine Research, 31: 247-254.

Sturm, R. 1998. Bericht über Ergebnisse der Süßwassermolluskenkartierung im Tennengau (Bundesland Salzburg). Salzburg, Univ. of Salzburg: 60 pp.

Sturm, R. 1999. Die Wasserschnecken und Muscheln in einem Nebenarm der Königsseeache (Bundesland Salzburg). Ein Beitrag zur Wassermolluskenkartierung im Tennengau. Linzer biol. Beitr., 31: 739-745.

Sturm, R. 2003. Species diversity and abundance of freshwater molluscs (Gastropoda et Bivalvia) in selected mountain lakes of the Central Alps in Austria. Malak. Abh., 21: 49-57.

Sturm, R. 2004. Freshwater molluscs (Gastropoda et Bivalvia) in selected mountain lakes of the Hohe Tauern, Austria: a contribution to the faunistic mapping of the Eastern Alps. Malak. Abh., 22: 23-36.

Sturm, R. 2005. Modelling optimum ranges of selected environmental variables for habitats colonized by the spring snail Bythinella austriaca (v. Frauenfeld, 1857) (Gastropoda, Prosobranchia). Malak. Abh., 23: 67-76.

Ter Braak, C.J.F. 1986. Canonical correspondence analysis: a new eigenvector technique for multivariate direct gradient analysis. Ecology, 67: 1167-1179.

Ter Braak, C.J.F. 1988. CANOCO-a FORTRAN program for canonical community ordination by [partial] [detrended] [canonical] correspondence analysis, principal components analysis and redundancy analysis. Groep Landbouwwiskunde Wageningen, Wageningen: $95 \mathrm{pp}$.

Ter Braak, C.J.F. \& P.F.M. Verdonschot. 1995. Canonical correspondence analysis and related multivariate methods in aquatic ecology. Aquat. Sci., 57: 255-289.

Turner, H., J.G.J. Kuiper, N. Thew, R. Bernasconi, J. Rüetschi, M. Wüthrich, \& M. Gosteli. 1998. Fauna Helvetica II: Atlas der Mollusken der Schweiz und Liechtensteins. Schweizer Entomologische Gesellschaft, Neuchatel: 527 pp.

Verdonschot, P.F.M. \& C.J.F. Ter Braak. 1994. An experimental manipulation of oligochete communities in mesocosms treated with chlorpyrifos or nutrient additions: multivariate analyses with Monte Carlo permutation tests. Hydrobiologia, 278: 251-266. 